\title{
【論文】
}

\section{指文字学習支援用空気圧式力覚提示グローブの開発 Finger Character Learning Support Pneumatic Haptic Presentation Glove}

\author{
吉満俊拓 (正会員)，多田章吾(非会員)
}

Toshihiro Yoshimitsu and Shougo Tada

\begin{abstract}
In self-learning of finger characters, it is difficult to understand stereoscopic motions such as hand shape, bending of fingers, how to move, with only planar information, while studying illustrations such as books.

We thought that the system of teaching the learner's fingers to the shape of the finger characters will deepen their understanding of how to move the fingers and allow fingertip learning to be carried out smoothly. We propose a teaching method based on force sense information that directly moves the learner's fingers instead of visual information by using the haptic presentation function for teaching of finger characters.

In this paper, we propose a pneumatic haptic presentation glove, which makes use of the characteristics of pneumatic actuator. The first is "Flexible artificial muscle haptic presentation glove" and the second is "Tendon driven haptic presentation glove". In these systems, the haptic presentation glove teaches finger characters by force sense presentation. We developed a haptic presentation glove aiming at learning finger characters learners assist fingers with the shape of finger characters by force sense presentation without relying on visual information.
\end{abstract}

\section{Key Words}

Finger character, Haptic presentation, Artificial muscle, Pneumatic actuator, Tendon drive

\section{1. はじめに}

手指の補助に関連したアシスト機器は主に事故や病気により 手に障害やマヒがある人を対象にしたリハビリ・機能回復目的や 日常生活で必要な握力の保持・動作の支援目的で多くの研究が なされている。

手指に関したアシスト機器は空気圧人工筋を内蔵し手首付近 についたスイッチの ON-OFF で空気圧を操作し手の開閉動作を 行う池田らの研究 1)や蛇腹のベローズ(空気袋)が膨張・収縮を繰 り返し行うことにより, 他動的・律動的に手指関節や手首関節の伸 展運動を行う山本らの研究 2)といったリハビリ支援・握力アシスト が目的の研究・開発が多くそれ以外の分野では少ないのが現

2017 年 12 月 20 日受付

2018 年 6 月 8 日掲載決定

神奈川工科大学創造工学部ロボットメカトロニクス学科,

干243-0292 神奈川県厚木市下荻野 1030

Dept. of Rbot and Mechatronics,

Kanagawa Institute of technology,

1030,Shimo-ogino,Atsugi,Kanagawa,243-0292,Japan
状である. 一方, 手話・指文字は, 聴覚障害者の視覚言語であり 大切なコミュニケーション方法である. 学習する方法は「講師に指

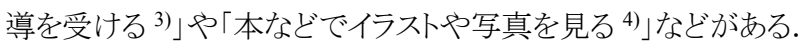

聴覚障害者の方や手話講師がそばにいるときは, 実際に手話 を実演してもらい学習できるが, 自己学習において, 本などのイラ ス卜を見ながらの学習は平面的な情報のみで手の形や手指の曲 げ方, 動かし方など立体的な動きを理解することが難しい.

手話・指文字の学習法の先行研究では, カメラから取得した距 離動画像を用いて手形状識別法を作成しそれを学習支援システ ムとした高林らの研究 5)やデータグローブのモーションキャプチャ システムを用いて 3D モデルを作成し手本動作の 3D モデルと比 較し修正していく岩峪らの研究 6)など, 教示された手指の動きに 対して自らの手指の動きが正しい動きをしているかどうか視覚で 確認する手法がある.

学習者の手指を直接「手話・指文字」の形状に力覚教示できる システムがあれば手指の動かし方などに対して理解が深まり「手 話・指文字」の学習を円滑に行えるようになるのではないかと考え, 手指アシスト機器の力覚提示機能を指文字の教示に用いること で, 手話の教示を視覚情報ではなく, 学習者の手指を直接動か す力覚情報による教示方法を提案する. 
本論文では,「屈曲式人工筋型力覚提示グローブ」と「腱駆動 型力覚提示グローブ」の 2 種を提案し, 指文字動作を力覚提示グ ローブが力覚教示する事により学習者が視覚情報に頼らず手指 が指文字の形状に力覚教示され, 学習者の指文字の理解と学習 を目的とした力覚提示グローブを開発する. なお本研究は, 神奈 川工科大学のヒトを対象とした研究に関わる倫理審査委員会で 承認されたもの(承認番号 20171212-01) である.

\section{2. カ覚提示グローブ概要}

\section{1 力覚提示グローブ}

指文字とは, 先述したようにひらがなの 50 音にあたる視覚言語 である. 清音以外にも濁音や半濁音, 拗音, 促音なども表現する 事が出来る. また, 指文字には, ひらがなとカタカナの区別はなく, 日本の指文字は全て片手で表現出来ることが特徵である.

指文字で「あし・す・と」の4字を提示した写真をFig.1に示す.

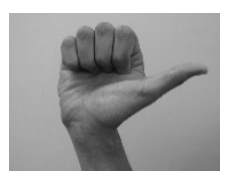

あ

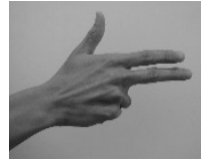

し

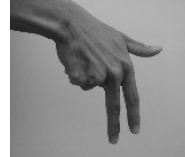

す

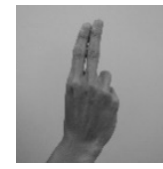

と
Fig.1 Finger character

写真のように, 指文字は手指と手首の屈曲伸展・内転外転を用 いて表現し, 濁音や半濁音, 拗音, 促音と一部の文字で前腕の 動きを加えることで表現をしている. 指文字学習において, 手指 の動きを力覚提示グローブによる力覚教示で学習者に伝えること ができれば高い指文字学習効果が見込まれる.

本論文は力覚提示グローブを用いた手指への力覚提示により 指文字学習の支援となる力覚提示機器を開発する. グローブで は手指への力覚提示を行うが, 手首・前腕の動きはグローブ状の 力覚提示機器では力覚提示の範囲を超えるため対象とはしない.

指文字学習支援用力覚提示グローブに求められる要件として,

- 50 音に対応する各指一の適切な力覚提示

・屈曲・伸展動作, 内転・外転動作を教示できる構造

・指の関節可動域を超えた動きをしない安全性 がある.

電動アクチュエータを用いた力覚提示機構では, 力制御が難 しく安全な力覚提示には角度を測定するセンサや指にかかる力 を測定するセンサなど安全装置をグローブに取り付ける必要があ り機器の複雑化を招く. それに対して, 空気圧を用いた力覚提示 では, 空気自体が持つ特性により特別なセンサをグローブに取り 付ける必要がなく, 供給圧力を検知する圧力センサにより, 力制 御が可能となりグローブ本体にセンサ類を必要としない.

また, 手指に関するアシスト機器では把持支援・握力アシストが 目的のため指の屈曲伸展動作には対応しているが，指の内転外 転動作機構を有していない.しかし, 指文字では指の屈曲伸展 動作に加え, 内転外転動作を用いて表現している.
そこで, 小型軽量で柔軟性を持つ空気圧の利点であるコンプ ライアンス制御の容易さを生かした力覚提示デバイスとして, 指の 屈曲伸展動作・内転外転動作に対応した指文字学習支援力覚 提示グローブを開発した. 本研究では, 力覚提示に空気圧式人 工筋肉を用いることとし, 力覚提示に適する機構の検討のため 2 種を提案し比較を行う.

第 1 は, 手指に対して直接力覚提示が可能な屈曲式人工筋肉 を用いて手指に直接力覚を教示する方式である. 屈曲式アクチ ユエータによる直接的な力覚教示で被験者に伝わりやすい. 反 面, 手掌にアクチュエータが取り付けられ手指の動きに制約が出 る恐れがある.

第 2 は, アクチュエータをグローブ本体から離すことで軽量化 が可能である腱張力により力覚を教示する腱駆動方式である. 腱 駆動式は手指部に腱を取り付けるためグローブ本体は軽量とな るが, 屈曲・伸展のために複数の腱を用いるため機構が複雑化 する.

\section{2 屈曲式人工筋型力覚提示グローブ}

提案する屈曲式人工筋型力覚提示グローブの概要図を Fig.2 に示す. 本機構は第1指から第 5 指の力覚提示グローブ本体手 背側に各 1 本ずつ屈曲型人工筋を取り付けている. 屈曲型人工 筋は後述するマッキベン型人工筋の片側にウレタン樹脂を取り付 けた構造である. 加圧した際に人工筋が収縮しウレタン樹脂が取 り付けられていない側へ屈曲を促す構造である.

力覚提示グローブ手背側のスペースの制約上各指 1 本のみ配 置したため屈曲・伸展動作のみ力覚提示を行う構造となっている. 屈曲式人工筋を含む力覚提示グローブ本体質量は $550 \mathrm{~g}$ である.

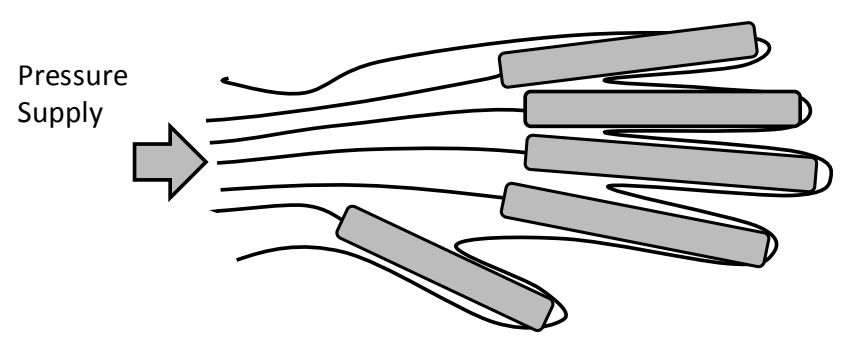

Haptic presentation glove Dorsal side

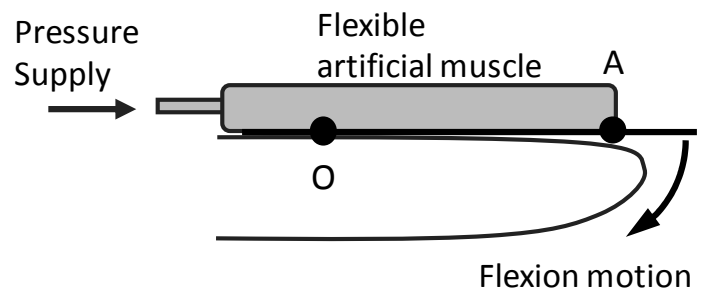

Fig.2 Flexible artificial muscle haptic presentation glove

\section{3 腱駆動型力覚提示グロ一ブ}

提案する腱駆動型力覚提示グローブの概要図を Fig.3 に示す. 本機構は, 手背側に 7 本, 手掌側に 5 本の腱を取り付けている.

各指の腱はグローブの指先で固定し, 手掌側と手背側の数箇 所で腱がずれないようガイドを設けてある. 腱の末端に張力発生 
用のマッキベン型人工筋が取り付けられており, 人工筋が収縮す ることで各指に力覚提示される.

手指に指文字の動きを伝達するため, 各指に屈曲伸展機構と, 内転外転機構を付与する. 指文字表現には屈曲・伸展動作のみ を行う指と, 伸展した状態で内転外転動作を行う指の 2 種の異な る力覚提示を行う必要がある.

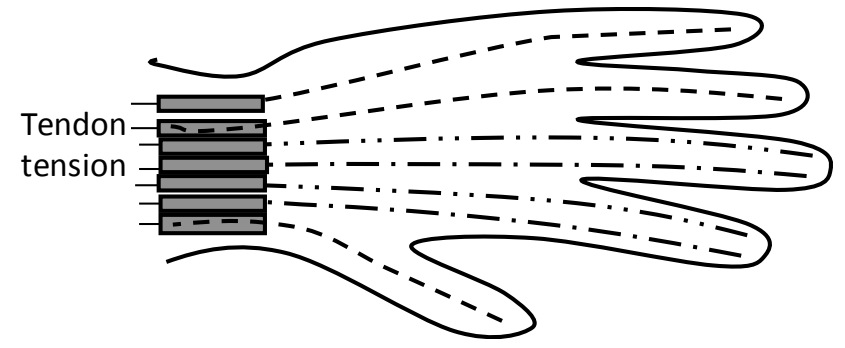

(a) Dorsal side

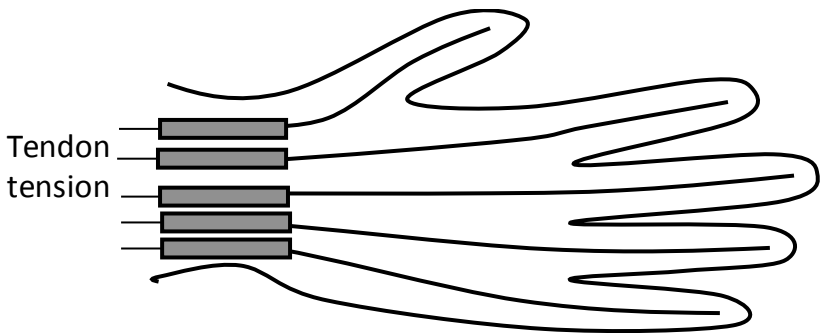

(b) Palm side

Fig.3 Tendon driven haptic presentation glove

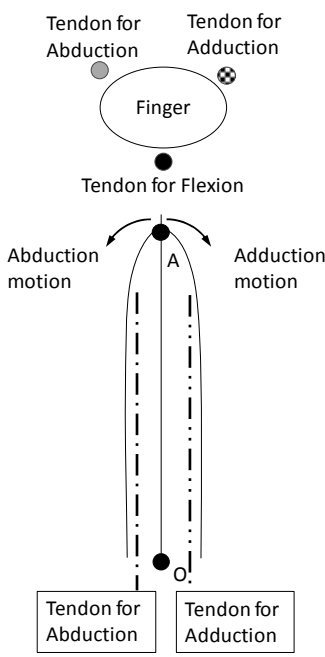

TYPE I

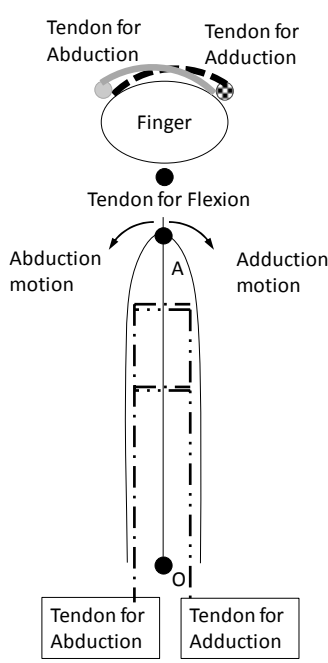

TYPE II
Fig.4 Tendon for adduction abduction motion

そこで, すべての指に内転外転動作を与えるのではなく, 指文 字の表現に必要と思われる指にのみ内転外転機構を付与する. 具体的には,

- 第 1 指・第 4 指・第 5 指の手背側に伸展用の腱を各 1 本

- 第 2 指・第 3 指には手背側に伸展動作・内転外転動作を 兼ねる 2 本の腱を配置

・ 第 1 指加第 5 指の手掌側に屈曲用の腱を各 1 本 のように配置をする.
屈曲伸展・内転外転動作のために 2 本または 3 本の腱の張力の 拮抗により力覚提示する機構を開発した. 第 2 指・第 3 指には Fig.4 に示すように内転外転動作用の腱を各指の手背側両側面 に配置した TYPE I と手背側両側面から第 1 関節・第 2 関節付 近の手背側に F の字状に配置した TYPE II の 2 種を製作し比較 を行った. 空気圧式人工筋を含む力覚提示グローブ本体質量は 650gである.

\section{3. 空気圧式人工筋}

本論文では円筒形のゴムチューブの外側に網組チューブを覆 わせた構造のマッキベン型人工筋を用いた. 網組チューブ端に 配管が固定されており，人工筋に高圧空気を供給すると内部の シリコンゴムチューブが膨張し網組チューブの編み込み角度が変 化し径方向に膨張し長手方向に収縮する. 構造が単純で, 用途 に合わせて直径や全長を自由に製作が可能である.

本研究で製作したマッキベン型人工筋は，シリコンゴム製ゴム チューブとポリエステル繊維製網組チューブを用いて製作した. 本論文で製作したマッキベン型人工筋を Fig.5 に, 緒元を Table 1 に示す. 空気圧供給部である点 $\mathrm{O}$ を固定し, O-A 間の距離を測 定し収縮率を求め, 先端部点 $\mathrm{A}$ にフォースゲージを取り付け収縮 方向を正とする発揮力を測定した.

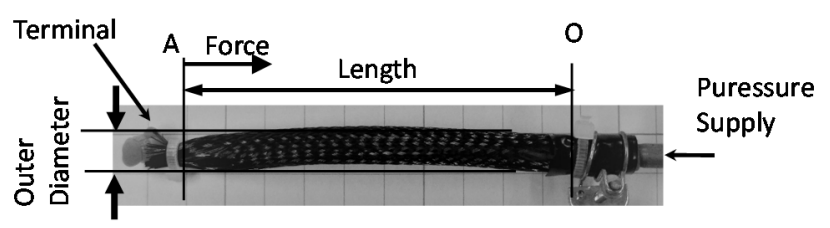

Fig.5 McKibben artificial muscle

Table 1 Specification table

\begin{tabular}{|l|r|r|r|}
\hline $\begin{array}{l}\text { Braided tube } \\
\text { weave width(mm) }\end{array}$ & 6.0 & 10.0 & 12.0 \\
\hline $\begin{array}{l}\text { Rubber tube } \\
\text { outer diameter(mm) }\end{array}$ & 5.0 & 7.0 & 9.0 \\
\hline $\begin{array}{l}\text { Outer diameter of } \\
\text { artificial muscle(mm) }\end{array}$ & 6.0 & 8.0 & 10.0 \\
\hline
\end{tabular}

\section{1 空気压式人工筋特性}

マッキベン型人工筋各特性を測定し, 力覚提示グローブ用ア クチュエータとして適する形状を決定する. 圧力一外径特性結果 を Fig.6 に, 圧力一出力特性結果を Fig.7 に示す. 自然長 150 $\mathrm{mm}$ ・外径 $6,8,10 \mathrm{~mm}$ の人工筋に $0.1 \mathrm{MPa} \sim 0.4 \mathrm{MPa}$ の圧縮空気を 印可し, 外径・発揮力を測定した. マッキベン型人工筋は空気圧 により収縮する際に力を発揮する構造上, 内径と出力に相関関 係があり, 加圧すると外径が膨張し, 全長は収縮する. 耐圧実験 として高圧の圧縮空気を供給したところ $0.5 \mathrm{M} \mathrm{Pa}$ を超えるとシリコ ンゴムチューブが塑性変形したため, 供給圧力を $0.4 \mathrm{MPa}$ までと する. 圧力上昇に比例し外径は約 $40 \%$ 増加した. それに対し, 発 揮力は圧力 $0.1 \mathrm{MPa}$ ではほとんど発生せず $0.2 \mathrm{MPa}$ から上昇し 10 〜28N となった. 


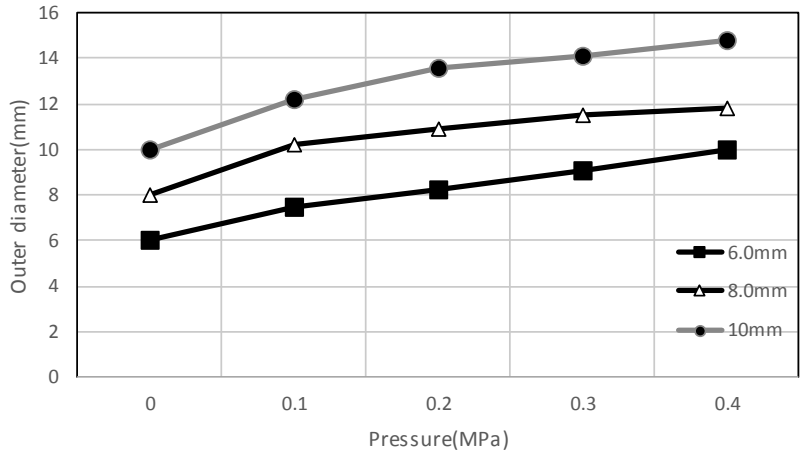

Fig.6 Relationship between pressure and outer diameter

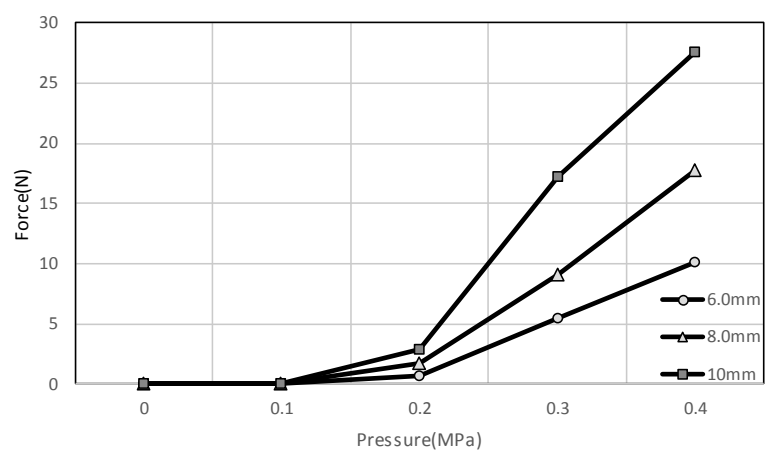

Fig.7 Relationship between pressure and contraction force

次に, 圧力一収縮特性結果を Fig.8 に示寸. 外径 $8 \mathrm{~mm}$ ・自然長 $50 \mathrm{~mm} \sim 300 \mathrm{~mm}$ の人工筋に対して, $0.1 \mathrm{MPa} \sim 0.4 \mathrm{MPa}$ の圧縮空 気を印可し, 人工筋の長さを測定した. $0.2 \mathrm{MPa}$ からの収縮が始ま り, $0.4 \mathrm{MPa}$ まで加圧する事で約 $15 \%$ 収縮する.

外径は圧力 $0.1 \mathrm{MPa}$ より変化するが, 発揮力・収縮率とも $0.2 \mathrm{MPa}$ まで変化が少ない. 本人工筋は構造上, 内部のシリコン ゴムチューブと網組チューブの間に若干の隙間がある. シリコン ゴムチューブの膨張初期は網組チューブが膨張せず編み込み 角度が変化しないため発揮力・収縮率ともに変化が少ないと考え られる。

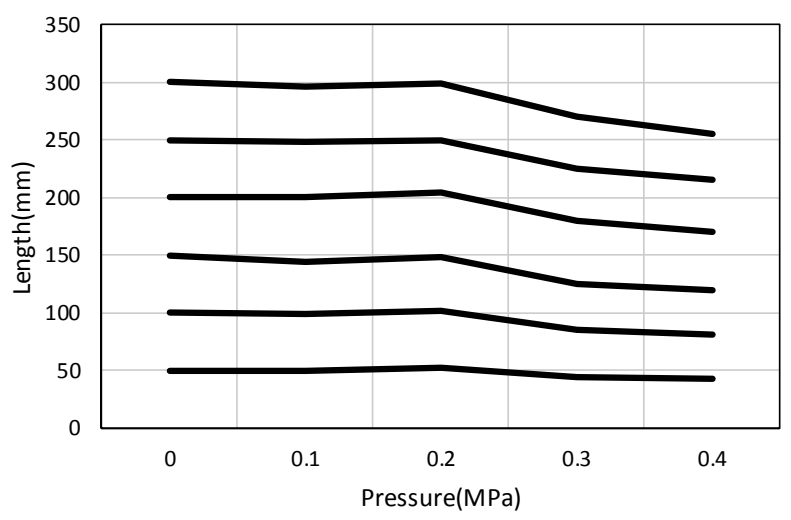

Fig.8 Relationship between pressure and actuator length

\section{2 届曲式人工筋}

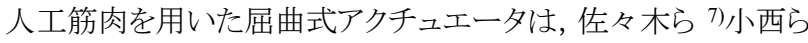
8)の伸長式ゴム人工筋の片側の繊維を強化した湾曲型アクチュ エータや, 佐々木ら ${ }^{9}$ による収縮式ゴム人工筋の内部に樹脂製の 薄板を挿入した湾曲型人工筋がある. 伸長式ゴム人工筋を用い た湾曲型アクチュエータは, 柔軟な構造を有しており加圧時に屈 曲力を発生するが, 非加圧時はベローズの弾性力のみとなり力 覚提示が難しい. 収縮式人工筋を用いた湾曲型アクチュエータ は, 薄板が曲がる方向は1方向に制限されているため屈曲伸展・ 内転外転動作を行うことができない。

本研究にて提案した屈曲式人工筋肉は, 指の屈曲伸展・内転 外転動作への力覚提示を行うことを目的として，1指に複数の人 工筇を取り付け, 屈曲動作を行いかつ内転外転動作時に障害と ならない柔軟なウレタン樹脂を芯材とした. ウレタン樹脂は柔らか いが, 弾性を持つため, 加圧時には屈曲方向へ, 排気時は伸展 方向へ力覚提示が可能であり, 外転内転動作を妨げず力覚提示 が可能な構造を有している.

マッキベン型ゴム人工筋を用いた屈曲式人工筋概要図を Fig.9 に示す. 屈曲式人工筋は, マッキベン型人工筋の片側にウレタン 樹脂を取り付けた構造をしている. 圧縮空気を供給すると人工筋 は収縮しようとするが, 上面はウレタン樹脂に固定されているため ほとんど収縮できない. 人工筫上下面の収縮率の違いにより屈曲 し, ウレタン樹脂の弾性を利用し減圧時に伸展する構造である. また構造上, 屈曲式人工筋の全長が短くなると屈曲力も低下寸る. 手背側に取り付けるため屈曲式人工筋の形状を自然長 $100 \mathrm{~mm}$ • 外径 $8 \mathrm{~mm}$ とした.

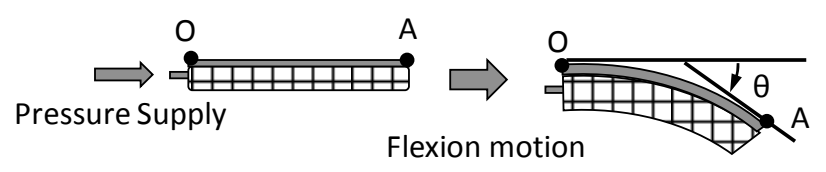

Fig.9 Flexible artificial muscle

屈曲式人工筋空気圧供給部である点 $\mathrm{O}$ を原点より屈曲方向で ある下向きを正とし人工筋先端部である点 A の接線の傾きを計 測する. 曲げモーメントは点 $\mathrm{O}$ を固定し, 点 $\mathrm{A}$ 直下にフォースゲ ージを設置し先端部荷重を測定し, 点 $\mathrm{O}$ 一点 $\mathrm{A}$ 間距離を腕の長 さとして時計回りを正とする曲げモーメントを算出する. 屈曲式人 工筋用実験装置概要を Fig.10 に示す.

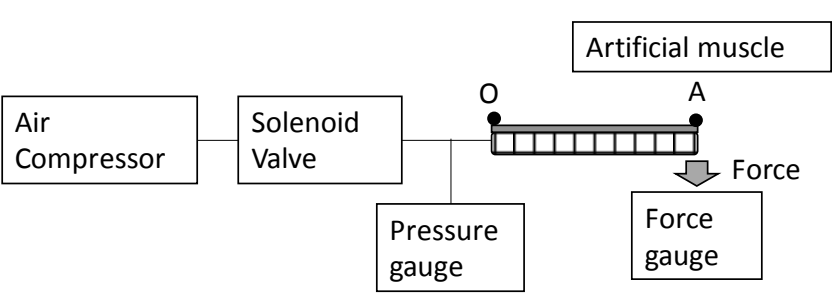

Fig.10 Experimental apparatus for artificial muscle

人工筋に $0.1 \mathrm{MPa} \sim 0.4 \mathrm{MPa}$ の圧縮空気を供給し, 加圧時の人工 
筋先端部角度とフォースゲージを用いて押し下げ力を測定した. 実験結果を Fig. 11 に示す. 0.1MPa より屈曲が始まるが曲げモー メントは発生せず $0.2 \mathrm{MPa}$ より曲げモーメントが発生し, $0.4 \mathrm{MPa}$ で 屈曲角度 26 度・曲げモーメント約 $6.0 \mathrm{~N} ・ \mathrm{~m}$ となった。

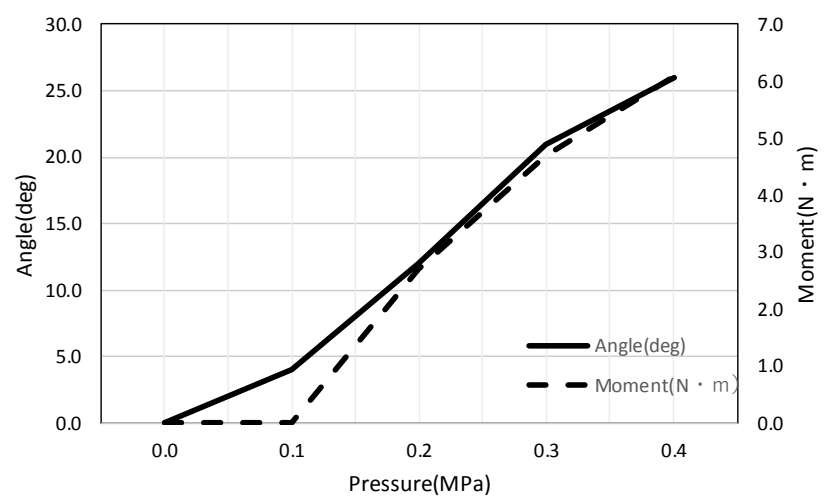

Fig.11 Relationship between angle and moment against pressure

\section{4. 力覚提示グローブ}

本機器は, 力覚提示グローブ本体と制御用組み込みマイコン によって構成されている. シリアル通信によりパソコンと接続され ており, 組み込みマイコンのサンプリングタイムは $50 \mathrm{~ms}, \mathrm{PC}$ と組 み込みマイコンは $250 \mathrm{~ms}$ 毎にデータ通信を行っている.

力覚提示手順を以下に示す.

1. 学習者がパソコンより学習したい指文字を入力する.

2. シリアル通信により組み込みマイコンへ指文字データが送信 される.

3. 組み込みマイコンが受信したデータに基づきソレノイドバル ブから圧縮空気が空気圧人工筋に供給される.

4. 力覚提示グローブが学習者の手指に対して力覚提示を行う.

5. 人工筋肉の内圧が供給圧と等しい場合 (土10\%以内), 力覚 提示がなされている旨, モニタ上に提示され, 10 秒後に圧 縮空気が排出され力覚提示が終了する.

6. 人工筋肉の内圧が供給圧より高い場合 $(+10 \%$ 以上 $)$, 正し い指文字形状を示すようにテキスト表示される

(例 第2指・内転動作 等)

7. 内圧が高い状態が5秒を超えた場合, 被験者の安全のため 圧縮空気が排出され力覚提示が終了する.

被験者は指文字未経験の手指に怪我・障害のない成人 10 名 (男性 6 名女性 4 名, 利き手: 右 10 名, 平均年齢 22 歳士 1 歳) と した. 実験前にインフォームドコンセントを取り実験を行った.

\section{1 屈曲式人工筋型力覚提示グローブ}

\subsection{1 屈曲角実験装置概要}

力覚提示グローブにより学習者の各指に対して屈曲伸展動作 を提示する必要がある. 屈曲式人工筋は全体が湾曲する構造で あるが, 手指の長さは第 1 指から第 5 指まで長さが異なり, 力覚 提示グローブに取り付けた状態における屈曲角度を求める必要 がある. そこで, 力覚提示グローブを被験者に装着し各指の屈曲 角度を測定した. 力覚提示グローブの第 1 指から第 5 指手背側
に屈曲式人工筋を取り付け屈曲角度の測定を行い, 被験者によ る装着実験を行った. 屈曲式人工筋肉には $0.3 \mathrm{MPa}$ を供給した. 実験装置概要を Fig.12 に示す.

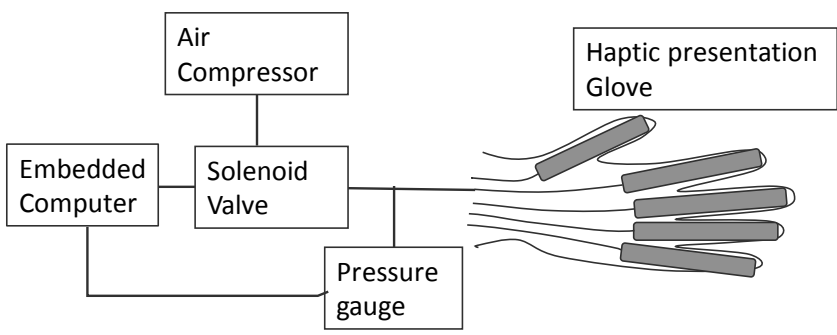

Fig.12 Experimental apparatus for flexible artificial muscle glove

\subsection{2 屈曲角実験結果}

Fig.2 の力覚提示グローブ本体 MP 関節部の点 $\mathrm{O}$ を原点とし て屈曲方向である下向きを正とし, 力覚提示グローブ本体指先端 の点 A の接線の傾きを計測した. 結果を Fig.13 に示す. 実験結 果より, 指長さと屈曲角度に相関がみられ, 第 3 指の屈曲角度が 一番高く, 第 1 指・第 5 指の屈曲角度がほかの指に比べ低い結 果となった. 力覚提示グローブへ十分な屈曲力を提供するため, 手指に同じ長さの人工筇を用いた. その結果, 指の長さの短い第 1 指や第 5 指の人工筋では手背部に取り付けられた部分が長く なり, 各指へ屈曲力が十分に伝わらなかったためと考えられる. ま た, 屈曲式人工筋は弧を描くように屈曲伸展し内転外転運動に 対応できないため, 教示できる指文字に限りがある.

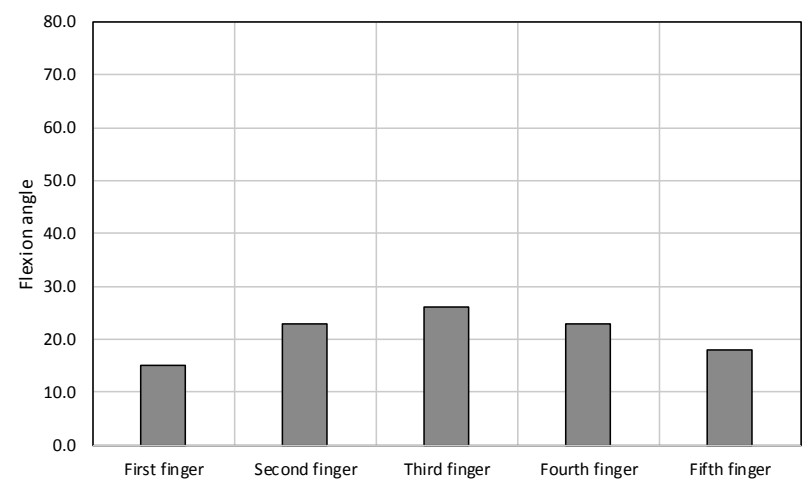

Fig.13 Measurement result of flexion angle of finger

\section{2 腱駆動型力覚提示グローブ}

\subsection{1 腱張力実験装置概要}

力覚提示グローブにより学習者の各指を屈曲伸展動作, 内転 外転動作させる腱張力を求める必要がある. また, 腱張力による 指関節への圧迫力が高くなると, 被験者の不快感・突き指の恐れ がある. そこで, 力覚提示グローブを被験者に装着し各指の屈曲 伸展動作・内転外転動作に必要かつ不快感や怪我の恐れのな い腱張力を測定した. 実験装置概要を Fig.14 に示す. 


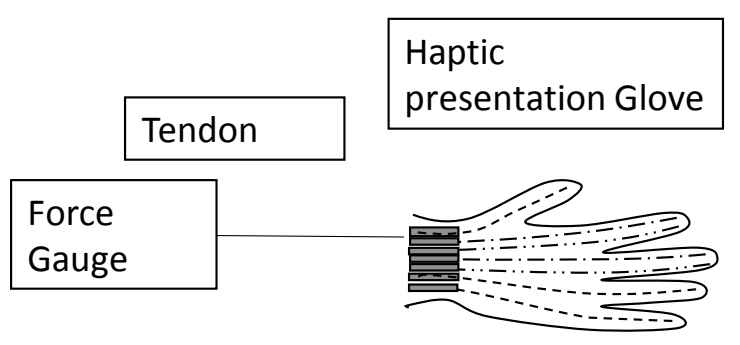

Fig.14 Experimental apparatus for tendon driving force

\subsection{2 腱張力実験結果}

腱張力測定方法は腱駆動型力覚提示グローブ第 1 指から第 5 指に取り付けられた各腱の末端に精密ステージに固定したフォ 一スゲージを取り付け, 被験者の手指が指文字の表現に十分な 角度まで屈曲伸展・内転外転する状態まで腱を引きフォースゲー ジの最大值を測定した. 実験中に不快感を抱いたり, 危険を感じ た場合はその時点で測定を終了する. 実験結果を Fig.15 に示す. 屈曲伸展動作では, 第 4 指・第 5 指の張力が高い傾向を示して いる. 内転外転動作では, TYPE I が TYPE II より張力が高い傾 向を示しているが, 各動作に対して腱張力が $8 \mathrm{~N}$ 以上あれば十分 な力覚提示が可能である. 以上より腱駆動式力覚提示グローブ に外径 $8 \mathrm{~mm}$, 自然長 $200 \mathrm{~mm}$ のマッキベン型人工筋を使用する こととする。

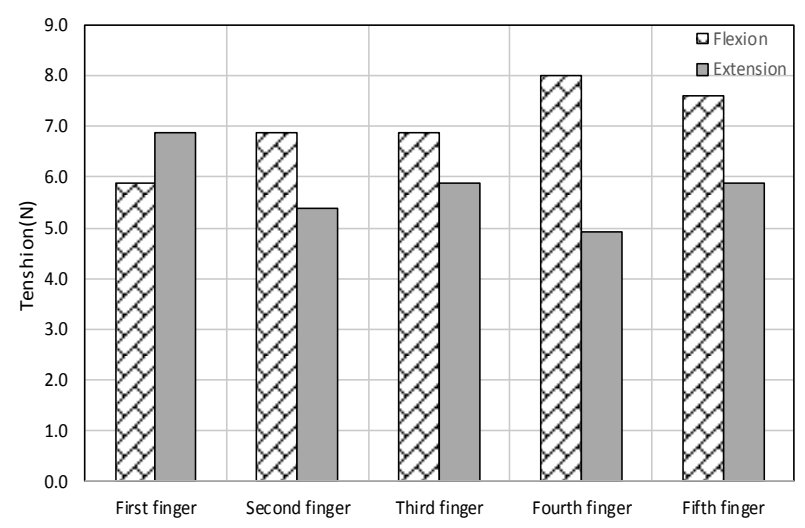

(A) Flexion extension motion

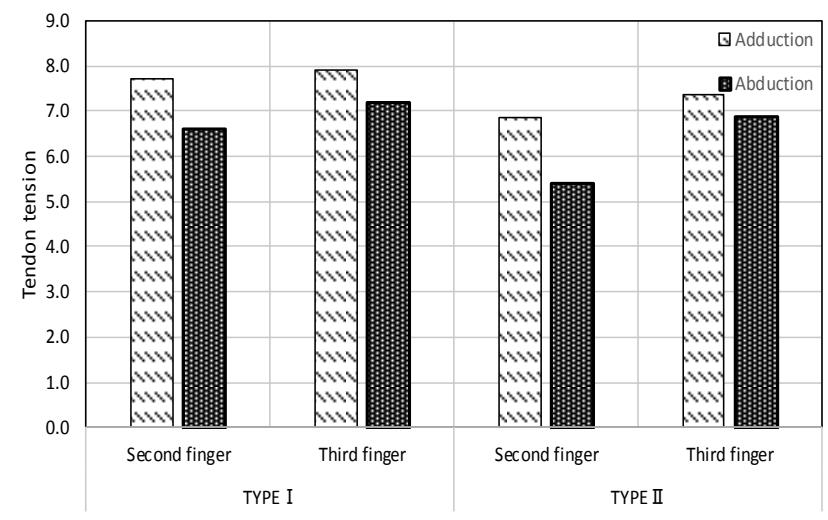

(B) Adduction abduction motion

Fig. 15 Measurement result of tendon tension

\subsection{3 屈曲角実験措置概要}

腱駆動型力覚提示グローブは, 手背側に 7 本手掌側に 5 本の 計 12 本の腱により, 第 1 指・第 4 指・第 5 指の屈曲伸展動作と第 2 指・第 3 指の内転外転動作に対して力覚提示する. ワイヤ端に マッキベン型人工筫を取り付け, 張力が約 $8 \mathrm{~N}$ となるようマッキベ ン型人工筋には $0.3 \mathrm{MPa}$ を供給した.

実験装置概要を Fig.16 に示寸.

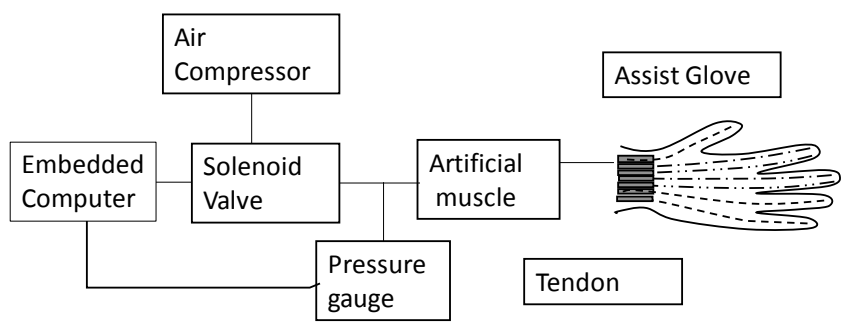

Fig.16 Experimental apparatus for tendon driven haptic presentation glove

\subsection{4 屈曲角実験結果}

屈曲角は Fig.2 の力覚提示グローブ本体 MP 関節部点 $\mathrm{O}$ を原 点として屈曲方向である下向きを正とし力覚提示グローブ本体指 先端の点 $\mathrm{A}$ の接線の傾きを計測した. 内転外転角は Fig.4 の力 覚提示グローブ本体 MP 関節部点 $\mathrm{O}$ を原点として力覚提示グロ ーブ本体指先端の点 $\mathrm{A}$ の接線の内転外転角を計測した. 屈曲 伸展動作実験では, 人工筋により各指の手掌側の腱に接続され た人工筋に圧縮空気を供給し屈曲動作を行う. 伸展動作におい ては腱の配置が指毎に異なるため, 第 1 指, 第 4 指, 第 5 指は手 背側の腱に接続された人工筋に圧縮空気を供給し, 第 2 指, 第 3 指は内転外転動作用の腱 2 本に接続された人工筧に圧縮空気 を供給した. 各指の力覚提示機構による力を検知できたかを評 価した. 評価方法は, 5 段階とし 5 に近いほど各指に力覚提示さ れたと評価とした. 屈曲伸展動作実験として, 手指の屈曲角度と 力覚提示性評価を行った. 実験結果を Fig.17, 18 に示す. 各指 の屈曲角度は 40〜60 度となり指文字の表現を行うに十分な可動 域を得た. 第 1 指の屈曲角度は他の指に比べ低いが力覚提示性 評価では他の指とそん色ない結果となった. 他の指では評価值も 高く屈曲伸展動作への力覚提示性も高い.

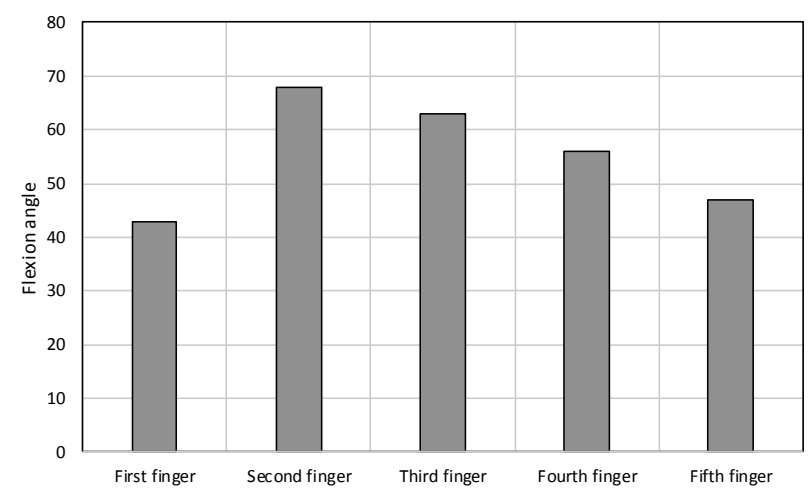

Fig.17 Measurement result of flexion angle of finger 


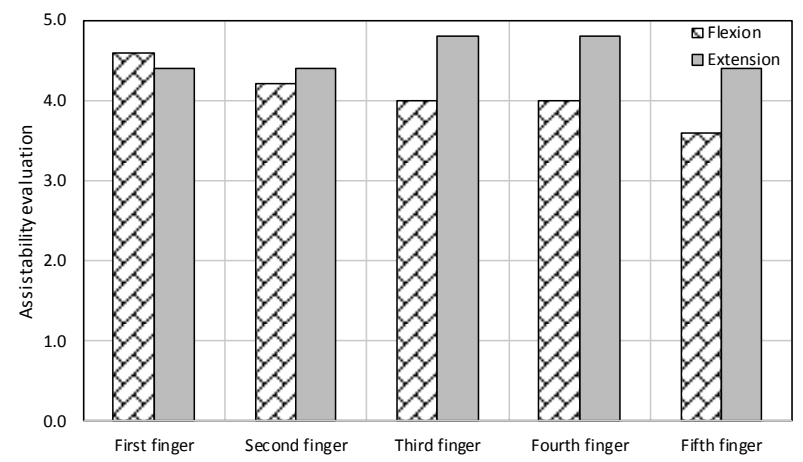

Fig.18 Result of Haptic presentation evaluation

次に, 内転外転動作実験として, 第 2 指と第 3 指の内転外転 角度と力覚提示性評価を行った. 結果を Fig. 19, 20 に示す. 指側 面に内転外転動作用腱を配置した TYPE I では, 内転外転角度 が小さく第 2 指と第 3 指の開閉動作は可能であるが指を交差させ ることができなかった. また, 力覚提示性評価においても評価は 高くなかった. 内転外転角度と力覚提示性評価が低い理由として,

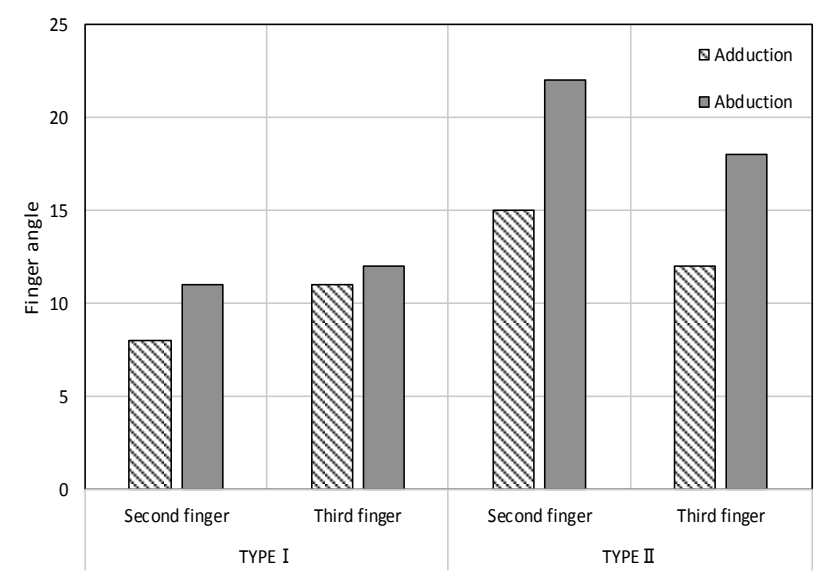

Fig.19 Measurement result of adduction abduction motion

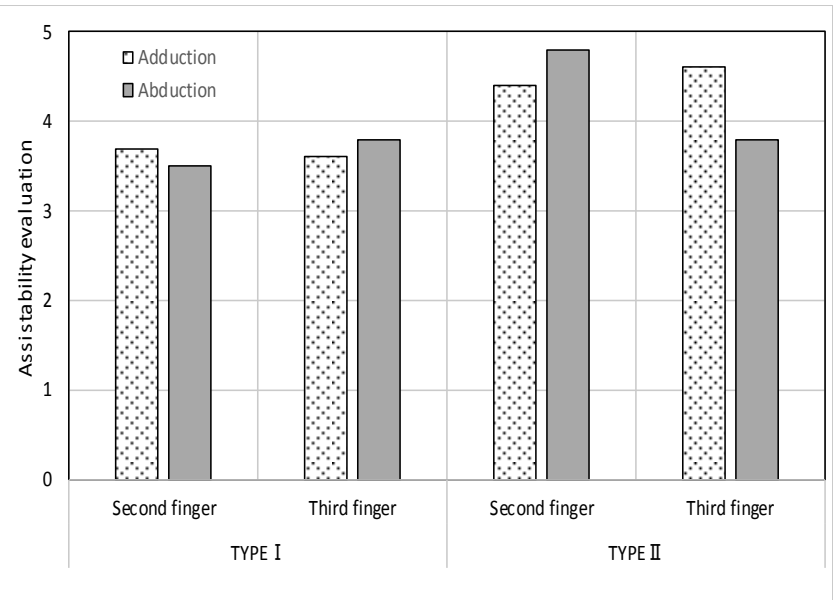

Fig.20 Result of Haptic presentation evaluation
指側面を腱が引くが, 手袋の側面が引かれ指に力が伝達されな かったと考えられる. 手指は第 3 関節を中心として内転外転する ため Type II では, 指全体に力が伝わるよう腱を一方向の側面か ら手背側を通り他方の側面まで F 字状に配置した. TYPE II では, 内転外転角度が内転方向に $10 \sim 15$ 度・外転方向に 20 度前後と 第 2 指と第 3 指の交差が可能であり指文字の表現を行うに十分 な可動域を得ることができた.

\section{3 指文字判読実験}

Fig.12, Fig.16 の実験装置を用いて屈曲式人工筋型力覚提示 グローブ・腱駆動型力覚提示グローブ TYPE II による指文字の判 読実験を行った. 対象とする指文字は清音 46 字とし, 実験方法 は力覚提示グローブを装着し被験者の手指を伸ばした状態から 実験装置により力覚提示された手指が教示された指文字を正しく 表現し, 判読できるかどうかを実験する. 日常生活において指文 字を使用している健常者に判読可否を判定していただき, 判読 可: $\bigcirc$, 手首動作を追加する必要があるが指形状は判読可: $\triangle$, 判読不可: ×とした. 実験結果を Table 2 に示す.

屈曲式人工筋型力覚提示グローブでは手指の屈曲伸展動作 のみのため, 46 字中 33 字の指文字が判読可能であった. 一例 を挙げると,「う」の様に屈曲伸展動作のみで教示できる指文字は 判読できるが, 屈曲伸展・内転外転動作で表す「か」は教示でき ないため, 判読不可となった. 取り付けスペースの制約で力覚提 示グローブに屈曲式人工筋のみを取り付けていたため教示でき る指文字が少ないことが原因である.

腱駆動型力覚提示グローブ TYPE II では, 指文字の表現に必 要な手指の屈曲伸展動作に加えて内転外転動作が可能なため, 46 字中 42 字で指文字を表すことができた. しかし, 大きな手首の 動きを必要とする「り」「ん」や, 指を動かしながら表現をする「の」 「も」が判読不可となった. 全ての指文字を教示するため, 手首・ 前腕の動きの力覚提示に加え, 動的に教示する必要がある.

Table 2 Experimental result of finger character determination (a) Finger character teaching result

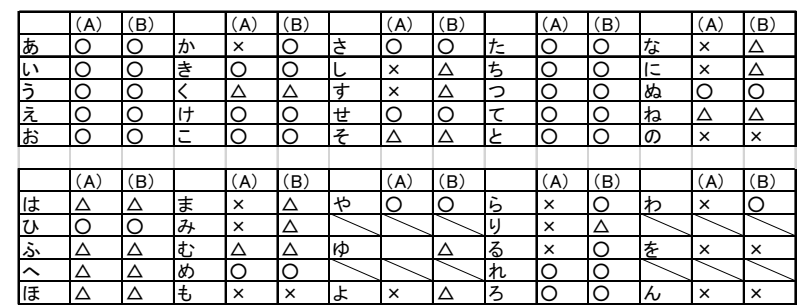

\section{O Readable}

$\triangle$ Readable but requires wrist action $\times$ Unreadable

(b) Number of teachable characters

\begin{tabular}{|l|c|c|r|}
\hline & $\bigcirc$ & $\triangle$ & $\times$ \\
\hline (A)Flexible artificial muscle assist glove & 21 & 12 & 13 \\
\hline (B)Tendon driven assist glove & 25 & 17 & 4 \\
\hline
\end{tabular}




\section{5. まとめ}

本論文では, 手指力覚提示機器の力覚提示機能を指文字・手 話の教示に用いることで, 手話・指文字の教示を視覚情報ではな く, 学習者の手指を直接動か寸力覚情報による教示方法を提案 した.

力覚提示グローブを指文字学習に用いる際には, 指の屈曲伸 展動作・内転外転動作ができることが求められる. そこで, 空気圧 の特性である圧縮性を積極的に活用し，柔軟性を有し力制御が 容易なマッキベン型人工筋を力覚提示用アクチュエータとし, カ 覚提示グローブ学習者の手指に対する力覚情報の提示方法とし $\tau$,

(1) 屈曲式人工筋を力覚提示グローブの手背側に直接取り付 けた「屈曲式人工筋型力覚提示グローブ」.

(2) 腱駆動機構により力覚提示グローブ各指が内転外転動作 を可能とした「腱駆動型力覚提示グローブ」

の 2 種を開発した.

指文字清音 46 字中, 屈曲式人工筋型では 33 字, 腱駆動型 TYPE II では 42 字表現寸ることができた. グローブ本体手背側の 取り付けスペースに限りがある屈曲式人工筋型では内転外転動 作のみとなり表現できる文字数が少ないが, 腱駆動型は取り付け 広いスペースを必要とせずグローブ本体に屈曲伸展・内転外転 動作が可能な機構を取り付けられ多くの指文字の表現が可能と なった. 清音に加え濁音や半濁音・拗音・促音を教示可能な力覚 提示グローブとして実用化するために, 今後とも研究を推進した い.

\section{参考文献}

1) 小川和徳, 池田智浩, 則次俊郎, 佐々木大輔, 着るだけで身 体の動きを支援するパワーアシストウェアの開発. ロボティクス・メ カトロニクス講演会講演概要集(CD-ROM) 2011: 1P1-A05.

2) 山本圭治郎, 装着型パワーアシストスーツ・ハンドの開発. 地 域ケアリング 2016; 18(1): 19-24.

3)一番ヶ瀬康子, 聴覚・言語障害者とコミュニケーション-形態別 介護技術「聴覚及び言語障害の介護」テキスト. 新訂版. 東京都 杉並区:一橋出版株式会社, 2007.

4) 社団法人東京都聴覚障害者連盟, イラストでわかる場面別つ かえる手話. 第 1 版. 東京都台東区: 株式会社新星出版社, 1997 . 5) 高林大輔, 大川泰弘, 瀬戸山浩平, 田中陽土, 加藤伸子, 岡 崎彰夫, 福井和弘, フィードバック機能を備えた指文字学習支援 システムの試作. 電子情報通信学会技術研究報告 $2013 ; 12$ (483): 79-84.

6) 岩峪和真，曽我真人，㴰寬和，データグローブを用いた指文 字動作スキル学習支援システムの構築。信学技報 2014; 114(305): 13-17.

7)佐々木大輔, 則次俊郎, 山本裕司, 高岩昌弘, 空気圧ゴム人 工筋を用いたパワーアシストグローブの開発. 日本ロボット学会 誌 2006; 24(5): 640-646.
8) 小西秀和, 則次俊郎, 高岩昌弘, 佐々木大輔, 筋電により人 間の意志を反映したパワーアシストグローブの制御、計測自動制 御学会論文集 2013; 49(1): 59-65.

9) 佐々木大輔, 則次俊郎, 高岩昌弘, 空気圧ゴム人工筋を用い た関節部装着型多自由度パワーアシスト装置の開発, 計測自動 制御学会システムインテグレーション部門講演会論文集(CDROM) 2003: 3D1-3. 